Acta Crystallographica Section D

Biological

Crystallography

ISSN 0907-4449

\section{Crystallization and preliminary X-ray analysis of shikimate dehydrogenase from Escherichia coli}

Shikimate dehydrogenase from Escherichia coli has been crystallized by the vapour-diffusion method using ammonium sulfate as a Received 14 October 1999 Accepted 9 February 2000

\author{
John Maclean, ${ }^{a}$ Samantha A. \\ Campbell, ${ }^{\mathbf{b}}$ Kevin Pollock, \\ Sureka Chackrewarthy, John R. \\ Coggins ${ }^{\mathrm{b}}$ and Adrian J. \\ Lapthorn $^{\mathrm{a} *}$
}

\footnotetext{
${ }^{a}$ Department of Chemistry, University of Glasgow, Glasgow G12 8QQ, Scotland, and ${ }^{\mathbf{b}}$ Division of Biochemistry and Molecular Biology, Institute of Biological and Life Sciences, University of Glasgow, Glasgow G12 8QQ, Scotland
}

Correspondence e-mail: a.lapthorn@chem.gla.ac.uk
(C) 2000 International Union of Crystallography Printed in Denmark - all rights reserved

precipitant. Mass spectrometry confirmed the purity of the enzyme and dynamic light scattering was used to find the appropriate additives to yield a monodisperse enzyme solution. The crystals are monoclinic, space group $C 2$, with unit-cell parameters $a=110.0$, $b=139.8, c=102.6 \AA, \beta=122.2^{\circ}$ (at $100 \mathrm{~K}$ ). Native crystals diffract to $2.3 \AA$ in-house on a rotating-anode X-ray source. The asymmetric unit is likely to contain four molecules, related by 222 symmetry, corresponding to a packing density of $2.86 \AA^{3} \mathrm{Da}^{-1}$.

\section{Introduction}

The shikimate pathway is essential to plants and microorganisms for the biosynthesis of aromatic compounds, but is absent from animals. The enzymes of this pathway are therefore potential targets for the development of non-toxic antimicrobial agents (Davies et al., 1994) and herbicides (Coggins, 1989).

Shikimate dehydrogenase (SDH; E.C. 1.1.1.25) catalyses the fourth reaction in the pathway, the NADPH-dependent reduction of 3-dehydroshikimate to shikimate. The protein from E. coli $\mathrm{K} 12$ has been purified to homogeneity (Chaudhuri \& Coggins, 1985) and shown to be a monomer of molecular weight $30 \mathrm{kDa}$. The gene (aroE) from E. coli for shikimate dehydrogenase has been cloned, sequenced and overexpressed at moderate levels (Anton \& Coggins, 1988).

SDHs represent a distinct group of dehydrogenases based on their amino-acid sequences. The only other obviously related dehydrogenases at the sequence level are the inducible quinate (shikimate) dehydrogenases from fungi and a gene product ydiB (of unknown function) found in the bacteria $E$. coli and Haemophilus influenzae. In most bacteria, $\mathrm{SDH}$ is present as a monomer, which is quite uncommon for dehydrogenases (Chaudhuri \& Coggins, 1985). In plants, SDH is linked with a type I dehydroquinase, forming a bifunctional enzyme (Deka et al., 1994), while in fungi such as Neurospora crassa, SDH forms the fourth domain of the pentafunctional AROM polypeptide (Lumsden \& Coggins, 1977), which catalyses five of the seven steps of the shikimate pathway.

The structure analysis of shikimate dehydrogenase will provide information about substrate recognition by the enzyme and will suggest how inhibitors could be designed. The relatively small size of SDH and the fact that it is a monomer makes the enzyme of interest to those wishing to investigate NADP-linked dehydrogenases.

\section{Overexpression of aroE}

The gene aroE has previously been expressed in a construct called pIA321 (Anton \& Coggins, 1988). This was produced by inserting a $1.27 \mathrm{kbp}$ fragment encoding the aroE gene into the plasmid pKK223 and was expressed in an E. coli aroE auxotrophic mutant AB2834. Expression in this system results in moderate expression of shikimate dehydrogenase with a 300 times higher specific activity for the enzyme in the crude extract in comparison with native E. coli $\mathrm{K} 12$.

PCR primers were designed to incorporate restriction sites for the enzymes NdeI and $B g l$ II. PCR was performed with DNA from pIA321 and Vent polymerase, resulting in a single fragment of $0.82 \mathrm{kbp}$. This fragment was cloned into pTB361, a T7 RNA polymerase expression plasmid (Studier \& Moffatt, 1986). Shikimate dehydrogenase expressed from this construct accounted for $30 \%$ of the total cellular protein.

\section{Enzyme purification and mass- spectrometric analysis}

Cells (14 g wet weight) were suspended in $20 \mathrm{ml}$ $10 \mathrm{~m} M$ Tris- $\mathrm{HCl} \mathrm{pH} 7.5$ containing $0.4 \mathrm{~m} M$ DTT and $1.3 \mathrm{~m} M$ EDTA (buffer $A$ ) and were broken by two passes through a French pressure cell operated at $6.55 \mathrm{MPa}$. This material was then diluted with $80 \mathrm{ml}$ buffer $A ; 0.5 \mathrm{mg}$ of DNAase was added and the mixture was left stirring at $277 \mathrm{~K}$; it was then centrifuged at $17000 \mathrm{rev} \mathrm{min}^{-1}$ for $1 \mathrm{~h}$. Shikimate dehy- 
Table 1

Dynamic light-scattering measurements of E. coli shikimate dehydrogenase.

The experiments were carried out on the same day using $1 \mathrm{mg} \mathrm{ml}^{-1}$ of enzyme at $293 \mathrm{~K}$. The values quoted are the mean values of at least 15 measurements. The hydrodynamic radius represents the median particle size present in the sample cell. The polydispersity indicates the standard deviation of the spread of particle sizes about the reported average radius. An increase in polydispersity relative to the average radius represents greater spread in the size distribution. The estimated $M_{w}$ is calculated from the hydrodynamic radius $\left(R_{H}\right)$ using an empirically derived relationship between the $R_{H}$ and $M_{w}$ values for a number of well characterized globular proteins in buffered solution.

\begin{tabular}{|c|c|c|c|c|}
\hline Additives & $\begin{array}{l}\text { Hydro- } \\
\text { dynamic } \\
\text { radius } \\
(\mathrm{nm})\end{array}$ & $\begin{array}{l}\text { Polydisper- } \\
\text { sity (nm) }\end{array}$ & $\begin{array}{l}\text { Estimated } \\
M_{w}\end{array}$ & $\begin{array}{l}\text { Count } \\
\left(\mathrm{s}^{-1}\right)\end{array}$ \\
\hline None & 2.8 & 1.2 & 35000 & 49300 \\
\hline NADPH $(5 \mathrm{~m} M)$ & 2.2 & - & 20000 & 31000 \\
\hline Shikimate $(5 \mathrm{~m} M)$ & 4.6 & 1.8 & 120000 & 57200 \\
\hline $\begin{array}{l}\text { NADPH }(5 \mathrm{~m} M)+ \\
\quad \text { shikimate }(5 \mathrm{mM})\end{array}$ & 7.1 & 4.0 & 340000 & 49300 \\
\hline
\end{tabular}

drogenase was purified from the resulting cell-free extract. All subsequent steps were performed at $277 \mathrm{~K}$.

Solid $\left(\mathrm{NH}_{4}\right)_{2} \mathrm{SO}_{4}$ was added to the supernatant to $30 \%$ saturation. The mixture was stirred for $15 \mathrm{~min}$ and the precipitate was then removed by centrifugation at $17000 \mathrm{rev} \mathrm{m^{-1 }}$ for $15 \mathrm{~min}$. The supernatant was adjusted to $55 \%$ saturation with solid $\left(\mathrm{NH}_{4}\right)_{2} \mathrm{SO}_{4}\left(162 \mathrm{~g} \mathrm{l}^{-1}\right)$ and stirred for $15 \mathrm{~min}$, followed by centrifugation as before. The precipitated protein was collected and dissolved in buffer $A$ and the sample was dialysed overnight against $50 \mathrm{~m} M$ Tris- $\mathrm{HCl}$ $\mathrm{pH}$ 7.5, $0.4 \mathrm{~m} M$ DTT and $50 \mathrm{~m} M \mathrm{KCl}$ (buffer $B)$.

The protein was loaded on to a DEAESephacel anion-exchange column $(21 \times$ $14 \mathrm{~cm}, 36 \mathrm{ml} \mathrm{h}^{-1}$ flow rate) which had been equilibrated with buffer $B$. The column was then washed with the same buffer until the $A_{280}$ of the eluate was less than 0.3. SDH was eluted with a linear gradient of

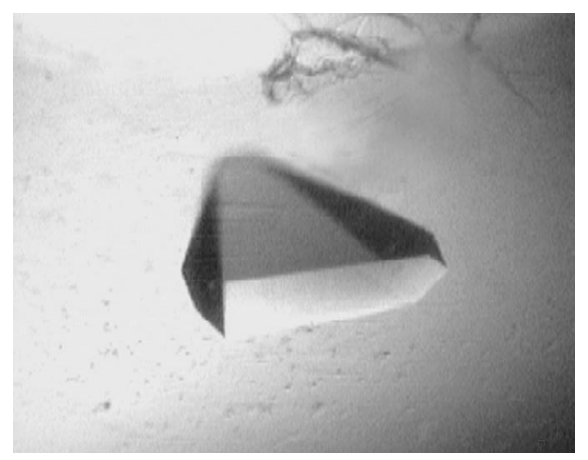

Figure 1

A crystal of E. coli shikimate dehydrogenase. The crystal is approximately $0.3 \times 0.3 \times 0.15 \mathrm{~mm}$ in size.

Figure 2
$50-350 \mathrm{mM} \mathrm{KCl}$ in $700 \mathrm{ml}$ buffer $B ; 6 \mathrm{ml}$ fractions were collected and assayed as described by Chaudhuri \& Coggins (1985). Fractions containing SDH activity were pooled and dialysed overnight against $25 \mathrm{~m} M$ Tris- $\mathrm{HCl} \mathrm{pH}$ 7.5, $0.4 \mathrm{~m} M$ DTT (buffer $C$ ).

The enzyme solution was concentrated by ultra-filtration against $50 \mathrm{~m} M$ Tris- $\mathrm{HCl} \mathrm{pH} 7.5$ containing $500 \mathrm{~m} M \mathrm{KCl}, 0.4 \mathrm{~m} M$ DTT and $20 \%(v / v)$ glycerol (buffer $D$ ). The concentrated protein was applied to a Sephacryl S200 (superfine grade) column $\left(8.5 \times 2.1 \mathrm{~cm}, 6 \mathrm{ml} \mathrm{h}^{-1}\right.$ flow rate) which had been equilibrated with buffer $D$. The enzyme was eluted with buffer D. Fractions containing SDH activity were pooled and dialysed overnight against buffer $C$.

The dialysed enzyme was loaded on to an ADP-Sepharose column ( $5 \mathrm{ml}$ bed volume) which had been equilibrated with buffer $C$. The column was eluted with buffer $C$ containing $0.1 \mathrm{mM}$ NADP. Fractions containing SDH activity were dialysed against buffer $C$ containing $50 \%(v / v)$ glycerol before long-term storage at $253 \mathrm{~K}$.

Mass spectrometry was performed on a VG Platform quadrupole mass spectrometer fitted with a pneumatically assisted electrospray source (VG Biotech Ltd, Altrincham,
Cheshire, England). For experimental details, see Krell et al. (1995). The purified protein was shown to be of high purity: a single species of molecular mass $29414 \mathrm{Da}$ was observed in the electrospray massspectrometry spectra, compared with a molecular weight of 29413.64 Da calculated from the DNA sequence.

\section{Dynamic light scattering}

Experiments were carried out using a DYNA-PRO 801 dynamic light-scattering/ molecular-sizing instrument (Protein Solutions, Buckinghamshire, England). Protein solutions $\left(1 \mathrm{mg} \mathrm{ml}^{-1}\right)$ were in $50 \mathrm{mM}$ Tris- $\mathrm{HCl} \mathrm{pH}$ 7.6. Dynamic light-scattering experiments were carried out in order to assess which combination of product and co-factor were appropriate to obtain a monodisperse enzyme solution. Monodispersity is not an infallible indicator that diffraction-quality crystals can be obtained from a protein; instead, it reflects the observation that monodisperse protein solutions have a much higher probability of producing crystals than those which are not (Ferré-D'Amaré \& Burley, 1997). Although several conditions were tried (Table 1), it was shown that monodispersity could only be achieved in the presence of NADPH. Inclusion of the product shikimate with or without co-factor led to significant aggregation. In the presence of NADPH, the estimated molecular weight obtained,

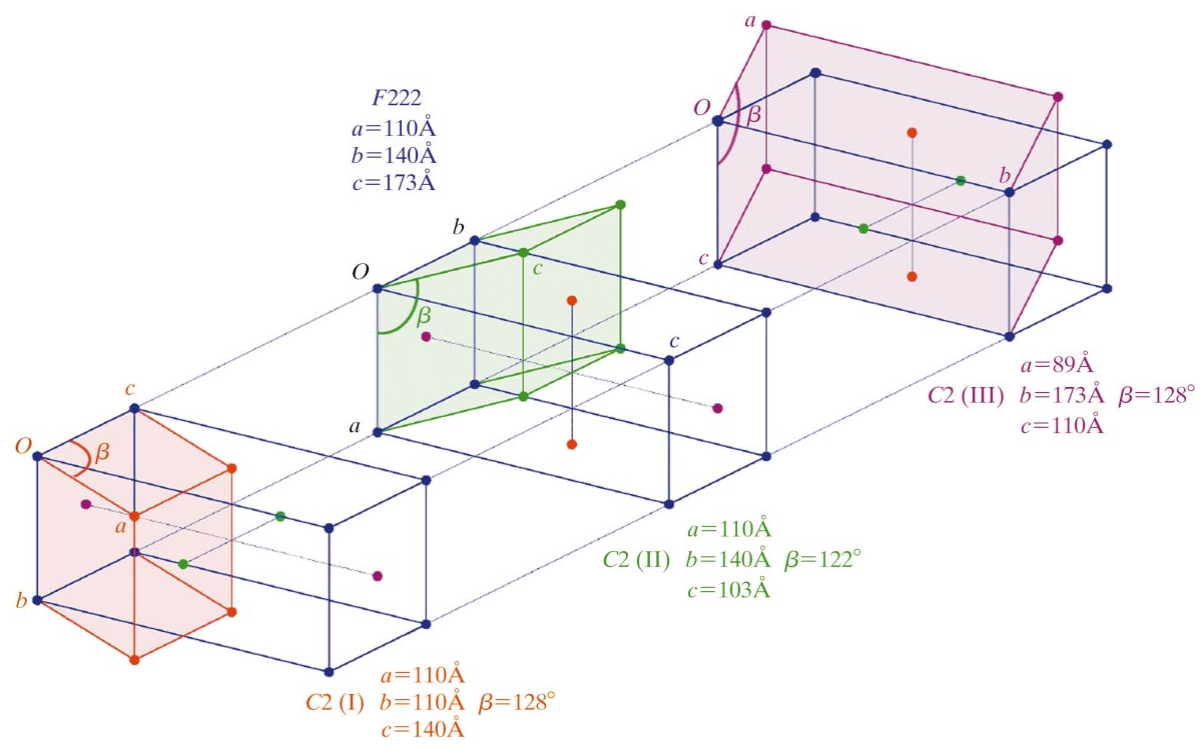

The three possible monoclinic cells (I-III) are shown in red, green and purple. They are superimposed on the original F222 cell, which is shown in blue. The F222 lattice points corresponding to the face centering are highlighted according to their use in the monoclinic lattices. The cell marked $C 2$ (II) and shown in green is the $C 2$ cell chosen as the true unit cell. 
Table 2

Statistics for the X-ray data.

(a) Processed in F222.

\begin{tabular}{llrlll}
\hline $\begin{array}{l}d_{\min } \\
(\AA)\end{array}$ & $R_{\text {sym }}(I)$ & $(I / \sigma)$ & $\begin{array}{l}\text { No. of unique } \\
\text { reflections }\end{array}$ & $\begin{array}{l}\text { Complete- } \\
\text { ness }(\%)\end{array}$ & $\begin{array}{l}\text { Multi- } \\
\text { plicity }(\%)\end{array}$ \\
\hline 4.91 & 0.068 & 26.5 & 3144 & 98.4 & 3.4 \\
3.90 & 0.072 & 26.2 & 3030 & 98.0 & 3.2 \\
3.41 & 0.095 & 20.8 & 3019 & 98.4 & 3.2 \\
3.09 & 0.146 & 14.5 & 3029 & 99.1 & 3.5 \\
2.87 & 0.230 & 9.2 & 3032 & 99.5 & 3.7 \\
2.70 & 0.290 & 6.7 & 3006 & 99.5 & 3.8 \\
2.57 & 0.356 & 5.5 & 3035 & 99.8 & 3.8 \\
2.46 & 0.411 & 4.3 & 3036 & 99.9 & 3.8 \\
2.36 & 0.466 & 3.5 & 3050 & 99.9 & 3.7 \\
2.28 & 0.521 & 2.9 & 2238 & 74.9 & 3.5 \\
Total & 0.141 & 14.1 & 29619 & 98.3 & 3.6 \\
\hline
\end{tabular}

(b) Processed in $C 2$.

\begin{tabular}{llrlll}
\hline $\begin{array}{l}d_{\min } \\
(\AA)\end{array}$ & $R_{\text {sym }}(I)$ & $(I / \sigma)$ & $\begin{array}{l}\text { No. of unique } \\
\text { reflections }\end{array}$ & $\begin{array}{l}\text { Complete- } \\
\text { ness }(\%)\end{array}$ & $\begin{array}{l}\text { Multi- } \\
\text { plicity }(\%)\end{array}$ \\
\hline 4.91 & 0.040 & 22.5 & 5741 & 95.0 & 2.2 \\
3.90 & 0.046 & 21.8 & 5854 & 97.8 & 2.1 \\
3.41 & 0.059 & 16.9 & 5878 & 98.7 & 2.1 \\
3.09 & 0.083 & 11.4 & 5923 & 99.4 & 2.1 \\
2.87 & 0.122 & 7.0 & 5940 & 99.7 & 2.0 \\
2.70 & 0.164 & 5.1 & 5886 & 99.8 & 2.0 \\
2.57 & 0.197 & 4.2 & 5942 & 99.7 & 2.0 \\
2.46 & 0.244 & 3.3 & 5925 & 99.4 & 2.0 \\
2.36 & 0.285 & 2.7 & 5903 & 99.2 & 2.0 \\
2.28 & 0.368 & 2.3 & 5546 & 94.3 & 1.9 \\
Total & 0.081 & 10.7 & 58538 & 98.3 & 2.0 \\
\hline
\end{tabular}

as would be expected. In the light of these results, crystallization trials were carried out in the presence of NADPH.

\section{Crystallization}

The enzyme was stored in $50 \%(v / v)$ glycerol, which was removed during concentration by Centricon-10 centrifugal concentrators (Amicon, Stonehouse, Gloucestershire, England). The enzyme was concentrated to $10 \mathrm{mg} \mathrm{ml}^{-1}$ in $10 \mathrm{~m} M$ Tris- $\mathrm{HCl} \mathrm{pH}$ 7.6, $0.4 \mathrm{~m} M$ DTT and $2.5 \mathrm{~m} M$ NADPH. Crystallization experiments were performed at $293 \mathrm{~K}$ using the sitting-drop vapour-diffusion technique. An exhaustive set of conditions, comprising commercially available and local sparsematrix screens (Jancarik \& Kim, 1991; Cudney et al., 1994) and linear screens were tried without success. Attempts to optimize conditions that had yielded promising crystalline precipitate were also unsuccessful.

$20000 \mathrm{Da}$, was a third lower than the molecular weight of the enzyme, but was consistent with the expected monomeric state of the enzyme. The apoenzyme gave a higher molecular-weight estimate, suggesting that addition of the cofactor results in significant closure of the structure,

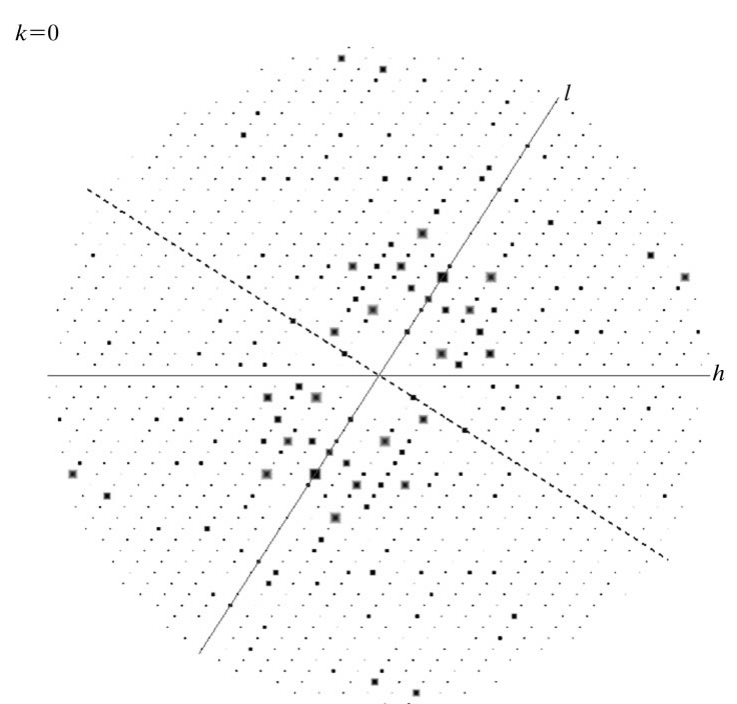

Figure 3

A pseudo-precession plot of the $h 0 l$ zone using data to $3.4 \AA$ calculated using the program HKLVIEW (Collaborative Computational Project, Number 4, 1994). In addition to $h 0 l=\bar{h} 0 \bar{l}$, an NCS twofold axis (marked with a dashed line) perpendicular to $l$ makes $h 0 l \simeq(h 0 \bar{l}=\bar{h} 0 l)$.
It was observed that the protein did not precipitate significantly in ammonium sulfate between $\mathrm{pH} 6.0$ and 7.0. The protein concentration was therefore increased to $20 \mathrm{mg} \mathrm{ml}^{-1}$ and a linear screen was constructed varying the $\mathrm{pH}$ between 5.8 and 7.0 using $100 \mathrm{~m} M$ cacodylate, PIPES, MOPS and BTP as buffers and a range of ammonium sulfate concentrations between 1.0 and $2.2 \mathrm{M}$. Two conditions, 1.7 and $1.9 \mathrm{M}$ $\left(\mathrm{NH}_{4}\right)_{2} \mathrm{SO}_{4}$ in cacodylate, yielded crystals. These initial $1.65 \mathrm{M}$ ammonium sulfate, $100 \mathrm{~m} M$ cacodylate buffer $\mathrm{pH}$ 5.8. Typically, $1.5 \mu \mathrm{l}$ of protein $\left(20 \mathrm{mg} \mathrm{ml}^{-1}\right)$ was mixed with an tion to form the drop. Crystals appeared after 10-12 d and continued to grow as bisphenoids to maximum dimensions of $0.3 \times 0.3 \times 0.15 \mathrm{~mm}$ (Fig. 1)

\section{X-ray analysis}

X-ray diffraction data were collected in-house on a Nonius FR591 rotating-anode generator using a MacScience DIP2000 imaging-plate system. conditions were optimized to equal volume of reservoir solu-
The crystals proved to be radiation-sensitive and therefore cryo-cooling was essential. Crystals were loop-mounted in a cryoprotectant containing $20 \%(\mathrm{v} / \mathrm{v})$ glycerol and were cryo-cooled to $100 \mathrm{~K}$ using an Oxford Cryosystems Cryostream. A native data set extending to $2.3 \AA$ resolution was collected using $1^{\circ}$ oscillation frames. Data were processed with $D E N Z O$ and scaled with SCALEPACK (Otwinowski, 1993). From autoindexing in $D E N Z O$, the crystals were found to index in a face-centred orthorhombic lattice corresponding to space group $F 222$, with unit-cell parameters $a=110.0$, $b=139.8, c=173.5 \AA$. An assumption of two molecules per asymmetric unit lead to an acceptable packing density, $V_{m}$, of $3.03 \AA^{3} \mathrm{Da}^{-1}$, corresponding to a solvent content of $60 \%$ (Matthews, 1968). However, merging the data in this space group gave poor statistics which were especially poor at high resolution (Table $2 a$ ) and involved a large number of rejections. The crystals were therefore scaled and merged in the monoclinic space group $C 2$, which is a subgroup of $F 222$, with unit-cell parameters $a=110.0$, $b=139.8, c=102.5 \AA, \beta=122.2^{\circ}$ (Table $2 b$ ). There were three possible $C 2$ cells (Fig. 2) as a consequence of the $F 222$ pseudo-lattice, so the monoclinic cell chosen was that which provided the best merging statistics. In $C 2$, an acceptable packing density is obtained for three to six molecules per asymmetric unit. A pseudo-precession plot of the X-ray data clearly shows an NCS twofold perpendicular to the crystallographic twofold (Fig. 3). Analysis of the self-rotation function showed two perpendicular twofold noncrystallographic symmetry (NCS) axes with correlation coefficients of $82 \%$; this pseudo222 symmetry indicated that the asymmetric unit contained four molecules, giving a $V_{m}$ of $2.86 \AA^{3} \mathrm{Da}^{-1}$ and a solvent content of $57 \%$. There are many examples of dehydrogenases whose quaternary structures are tetrameric and show 222 symmetry. This arrangement may be reflected in the NCS present in shikimate dehydrogenase, although gel filtration (Chaudhuri \& Coggins, 1985) and dynamic light-scattering studies (reported here) have shown the protein to be monomeric under physiological conditions. We have attempted to solve the structure by molecular replacement with AMoRe (Navaza, 1990) using various dehydrogenases including lactate dehydrogenase (PDB code 1ldn), NADPdependent alcohol dehydrogenase (1kev), and porcine mitochondrial acyl-COA dehydrogenase ( $0 \mathrm{acd}$, now obsolete) as search models. These attempts have been without success and the structure will therefore be 
solved by multiple isomorphous replacement.

This research was supported by BBSRC and the University of Glasgow. We would like to especially thank Mr John Greene and Dr Tino Krell for technical assistance in protein purification and mass spectrometry, and Dr Aleksander Roszak for useful discussions.

\section{References}

Anton, I. A. \& Coggins, J. R. (1988). Biochem. J. 249, 319-326.
Chaudhuri, S. \& Coggins, J. R. (1985). Biochem. J. 226, 217-223.

Coggins, J. R. (1989). In Herbicides and Plant Metabolism, edited by A. Dodge. Cambridge University Press.

Collaborative Computational Project, Number 4 (1994). Acta Cryst. D50, 760-763.

Cudney, R., Patel, S., Weisgraber, K., Newhouse, Y. \& McPherson, A. (1994). Acta Cryst. D50, 414-423.

Davies, G. M., Barrett-Bee, K. J., Jude, D. A., Lehan, M., Nichols, W. W., Pinder, P. E., Thain, J. L., Watkins, W. J. \& Wilson, R. G. (1994). Antimicrob. Agents Chemother. 38, 403-406.

Deka, R. K., Anton, I. A., Dunbar, B. \& Coggins, J. R. (1994). FEBS Lett. 349, 397-402.

Ferré-D'Amaré, A. R. \& Burley, S. K. (1997). Methods Enzymol. 276, 157-166.
Ferrige, A. G., Seddon, M. J., Green, B. N., Jarvis, S. A. \& Skilling, J. (1992). Rapid Commun. Mass Spectrom. 6, 707-711.

Jancarik, J. \& Kim, S.-H. (1991). J. Appl. Cryst. 24, 409-411.

Krell, T., Pitt, A. R. \& Coggins, J. R. (1995). FEBS Lett. 360, 93-96.

Lumsden, J. \& Coggins, J. R. (1977). Biochem. J. 161, 599-607.

Matthews, B. W. (1968). J. Mol. Biol. 33, 491-497.

Navaza, J. (1990). Acta Cryst. A46, 619-620.

Otwinowski, Z. (1993). Proceedings of the CCP4 Study Weekend. Data Collection and Processing, edited by L. Sawyer, N. Isaacs \& S. Bailey, pp. 56-62. Warrington: Daresbury Laboratory.

Studier, F. W. \& Moffatt, B. A. (1986). J. Mol. Biol. 189, 113-130. 